\title{
PENGARUH PERPUTARAN KAS DAN PERPUTARAN PERSEDIAAN TERHADAP LIKUIDITAS PADA PT INDOFOOD CBP SUKSES MAKMUR TBK YANG TERDAFTAR DI BURSA EFEK INDONESIA PERIODE 2011-2018
}

\author{
Dewi Silvia ${ }^{1}$, Yulistina $^{2}$, Tia Anggraini $^{\mathbf{3}}$ \\ Program Studi Akuntansi Fakultas Bisnis ${ }^{123}$ \\ Universitas Mitra Indonesia ${ }^{123}$ \\ dewisilvia@umitra.ac.id ${ }^{1}$ \\ yulistina@umitra.ac.id ${ }^{2}$ \\ Anggrainitia066@gmail.com ${ }^{3}$
}

\begin{abstract}
ABSTRAK
Penelitian ini bertujuan untuk mengetahui seberapa besar pengaruh perputaran kas dan perputaran persediaan terhadap likuiditas pada PT Indofood CBP Sukses Makmur Tbk. Populasi penelitian ini adalah laporan keuangan PT Indofood CBP Sukses Makmur Tbk. Jumlah sampel dalam penelitian ini adalah 32 dengan menggunakan teknik simple random sampling. Alat analisis menggunakan uji asumsi klasik, regresi linier berganda, koefisien determinasi dan pengujian hipotesis. Hasil penelitian menunjukkan secara simultan perputaran kas dan perputaran persediaan berpengaruh dan signifikan terhadap likuiditas (rasio cepat) pada PT Indofood CBP Sukses Makmur Tbk dan secara parsial perputaran kas berpengaruh negatif dan signifikan terhadap likuiditas (rasio cepat), perputaran persediaan berpengaruh dan signifikan terhadap likuiditas (rasio cepet) pada PT Indofood CBP Sukses Makmur Tbk.
\end{abstract}

Kata Kunci: perputaran kas, perputaran persediaan, likuiditas (rasio cepat)

\section{PENDAHULUAN}

Semakin berkembangnya dunia bisnis maka semakin tinggi persaingan yang akan dihadapi perusahaan, terutama yang memiliki bisnis yang sejenis, dalam menghadapi persaingan perusahaan dituntut untuk dapat mempertahankan kelangsungan usahanya dengan berbagai cara. Diantaranya dengan membuat keputusan-keputusan yang manunjang untuk pencapaian tujuan perusahaan dimasa yang akan datang, sehingga perusahaan dapat terus meningkatkan kemampuan dalam bersaing.

Pelemahan nilai tukar rupiah terhadap dolar Amerika Serikat (AS) selama beberapa waktu terakhir terus memberi tekanan terhadap perolehan margin perusahaan makanan dan minuman, terutama pada perusahaan yang memiliki ketergantungan besar terhadap bahan baku impor. Magrin perusahaan tertekan akibat biaya produksi yang terus meningkat tanpa mampu diimbangi dengan kenaikan harga jual.

Margin rata-rata perusahaan makanan dan minuman telah menyusut antara 3\%-5\%. Biaya produksi rata-rata perusahaan makanan dan minuman terus mengalami lonjakan. Untuk dapat tumbuh dan berkembang suatu perusahaan diperlukan suatu penanganan dan pengelolaan aset perusahaan yaitu kas dan persediaan yang baik agar penggunaan sumber daya yang dimiliki oleh perusahaan dapat digunakan dengan baik sehingga dapat menghasilkan keputusan-keputusan yang 
menunjang tujuan perusahaan dimasa yang akan datang, serta mampu memenuhi kewajiban (utang) perusahaan yang telah jatuh tempo, sehingga perusahaan dapat terus meningkatkan kemampuannya

\section{TINJAUAN PUSTAKA}

\subsection{Perputaran Kas}

Menurut Bambang Riyanto, 2013, 210; Perputaran kas merupakan periode berputarnya kas yang dimulai saat kas diinvestasikan dalam komponen modal kerja sampai saat kembali menjadi kas-kas sebagai unsur modal kerja yang paling tinggi likuiditasnya.

\subsection{Perputaran Persediaan}

Menurut Munawir, 2012, 119; Tingkat perputaran persediaan (inventory trun over), menunjukkan berapa kali persediaan tersebut diganti dalam arti dibeli dan dijual kembali. Semakin tinggi perputaran persediaan tersebut maka jumlah modal yang dibutuhkan semakin rendah.

\subsection{Rasio Likuiditas}

Menurut Kasmir, 2014, 129; Rasio likuiditas (liquidity ratio) merupakan rasio yang menggambarkan atau mengukur kemampuan perusahaan dalam memenuhi kewajiban (utang) jangka pendek.

\subsection{Rasio Cepat (Quick Ratio)}

Menurut Kasmir, 2014, 134; Rasio cepat (quick ratio) merupakan rasio yang menunjukan kemampuan perusahaan dalam memenuhi, membayar kewajiban atau utang lancar (utang jangka pendek) dengan aktiva lancar tanpa memperhitungkan nilai sediaan (inventory).

\section{METODE PENELITIAN}

Penelitian yang akan dilakukan bersifat kuantitatif. Penelitian ini dilakukan di IDX lampung. Sumber data penelitian ini menggunakan data sekunder. Populasi dalam penelitian ini adalah laporan keuangan PT Indofood CBP Sukses Makmur Tbk periode 2011-2018 yaitu sebanyak 32 sampel dalam bentuk triwulan. Teknik pengambilan sampel yang digunakan adalah menggunakan Simple Random Sampling.

\section{PEMBAHASAN DAN HASIL}

\subsection{Hasil Penelitian}

\section{Uji Asumsi Klasik}

a. Uji Normalitas

Uji Normalitas bertujuan untuk menguji apakah dalam model regresi, antara variabel bebas terdistribusi secara normal atau tidak. Pengujian normalitas data menggunakan Test of Normality Kolmogrove-sminov. Dasar pengambilan keputusan bisa dilakukan berdasarkan probabilitas (Asymtotic Sigficance) yaitu: jika probabilitas > 0,05 maka dinyatakan distribusi normal dan jika probabilitas $<0,05$ 
maka dinyatakan distribusi tidak normal Hasil output uji normalitas sebagai berikut :

Tabel 1. Uji Normalitas

\section{One-Sample Kolmogorov-Smirnov}

\section{Test}

\begin{tabular}{|c|c|c|}
\hline & & $\begin{array}{c}\text { Unstandardized } \\
\text { Residual }\end{array}$ \\
\hline \multicolumn{2}{|l|}{$\mathrm{N}$} & 32 \\
\hline Normal & Mean & ,0000000 \\
\hline Parameters $^{\mathrm{a}, \mathrm{b}}$ & Std. Deviation & ,23105128 \\
\hline $\begin{array}{l}\text { Most Extreme } \\
\text { Differences }\end{array}$ & Absolute & ,101 \\
\hline & Positive &, 101 \\
\hline & Negative &,- 059 \\
\hline \multicolumn{2}{|l|}{ Test Statistic } &, 101 \\
\hline \multicolumn{2}{|c|}{ Asymp. Sig. (2-tailed) } & $200^{\mathrm{c}, \mathrm{d}}$ \\
\hline
\end{tabular}

Berdasarkan tabel diatas hasil uji normalitas yang mengunakan one sample kolmogorov-smirnov test adalah nilai signifikansi sebesar 0,200. Model regresi akan memenuhi asumsi normalitas jika nilai Asymp Sig (2-tailed) > 0,05 yang menunjukan bahwa data terdistribusi normal. Dari data diatas hasil terdistribusi secara normal karena Asymp. Sig. (2-tailed) adalah 0,200 lebih besar dari tarif signifikan 0,05.

b. Uji Heteroskedastisitas

Berdasarkan grafik Sccatterplot diatas dapat dilihat bahwa titik-titik menyebar diatas dan dibawah angka 0 pada sumbu Y, maka kondisi ini menunjukan tidak terjadi heteroskedastisitas

c. Uji Autokorelasi

Berdasarkan hasil uji autokorelasi dengan menggunakan Runs Test untuk likuiditas (quick ratio) dapat dilihat bahwa nilai Asymp. Sig. (2-tailed) adalah 0,590, berarti tingkat signifikannya $>0,05$ sehingga tidak terjadi autokorelasi dan model regresi dapat digunakan.

\subsection{Uji Regresi Linier Berganda}

Hasil Persamaan regresi linier berganda sebagai berikut:

Tabel 2. Persamaan Regresi Linier Berganda

\section{Coefficients $^{\text {a }}$}

\begin{tabular}{|c|c|c|c|c|c|}
\hline \multirow[b]{2}{*}{ Model } & \multicolumn{2}{|c|}{$\begin{array}{c}\text { Unstandardized } \\
\text { Coefficients }\end{array}$} & \multirow{2}{*}{$\begin{array}{c}\text { Standardized } \\
\text { Coefficients }\end{array}$} & \multirow[b]{2}{*}{$\mathrm{t}$} & \multirow[b]{2}{*}{ Sig. } \\
\hline & B & $\begin{array}{l}\text { Std. } \\
\text { Error }\end{array}$ & & & \\
\hline 1 (Constant) & 1,905 & 107 & & 17,789 &, 000 \\
\hline $\begin{array}{l}\text { Perputaran } \\
\text { Kas }\end{array}$ &,- 190 & ,059 & $-1,063$ & $-3,229$ & ,003 \\
\hline $\begin{array}{l}\text { Perputaran } \\
\text { Persediaan }\end{array}$ & ,108 & ,038 & ,931 & 2,828 & ,008 \\
\hline
\end{tabular}

a. Dependent Variable: Quick Ratio

Sumber: data diolah, 2018

Berdasarkan tabel diatas hasil uji regresi linier berganda diketahui bahwa persamaan regresi linier berganda adalah :

$\mathrm{Y}=1,905-0,190 \mathrm{X}_{1}+0,108 \mathrm{X}_{2}+\mathrm{e}$

Dari persamaan tersebut, dapat dijelaskan sebagai berikut :

a. Nilai konstanta sebesar 1,905 artinya jika perputaran kas dan perpuatan persediaan bernilai tetap, maka nilai likuiditas (quick ratio) sebesar 1,905.

b. Koefisien regresi $\left(\mathrm{X}_{1}\right)$ perputaran kas sebesar $(-0,190)$, hal ini menunjukkan bahwa perputaran kas memiliki hubungan negatif atau berbanding terbalik dengan likuiditas (quick ratio), artinya jika perputaran kas meningkat sebesar satu satuan, maka akan menurunkan tingkat likuiditas likuiditas (quick ratio) sebesar 0,190, dan sebaliknya, jika perputaran kas 
turun sebesar satu-satuan, maka akan meningkatkan likuiditas (quick ratio) sebesar 0,190, dengan asumsi varaibel bebas lainnya konstan

c. Koefisien regresi $\left(\mathrm{X}_{2}\right)$ perputaran persediaan sebesar 0,108 , hal ini menunjukkan jika perputaran persediaan memiliki hubungan positif atau berbanding lurus dengan likuiditas (quick ratio), artinya jika perputaran persediaan naik sebesar satu satuan, maka akan meningkatkan likuiditas (quick ratio) sebesar 0,108, dan sebalikknya jika perputaran persediaan turun sebesar satusatuan, maka quik ratio juga kan mengalami penurunan sebesar 0,108, dengan asusmsi variabel bebas lainnya kontsan.

\subsection{Uji Hipotsis}

Hasil uji hipotesisi parsial, berdasarkan tabel 2 variabel perputaran kas diperoleh nilai $t_{\text {hitung }}$ sebesar $-3,229>$ nilai $t_{\text {tabel }}$ 2,045 dengan nilai signifikan sebesar $0,003<0,05$, sehingga dapat disimpulkan bahwa perputaran kas berpengaruh negatif dan signifikan secara parsial terhadap likuiditas (quick ratio). Sedangkan, variabel perputaran persediaan diperoleh nlai $\mathrm{t}_{\text {hitung }}=$ $2,828>$ nilai $t_{\text {tabel }} 2,045$ dengan nilai signifikan sebesar 0,008 $<0,05$. Maka dapat disimpulkan, bahwa perputaran persediaan berpengaruh positif dan signifikan secara parsial terhadap likuiditas (quick ratio).
Hasil uji hipotesis simultan tersaji pada tabel dibawah ini :

Tabel 4. Hasil Uji Hipotesis Simultan

ANOVA $^{\mathrm{a}}$

\begin{tabular}{|c|c|c|c|c|c|}
\hline Model & $\begin{array}{l}\text { Sum of } \\
\text { Squares }\end{array}$ & $\begin{array}{l}\text { D } \\
\mathrm{f}\end{array}$ & $\begin{array}{l}\text { Mean } \\
\text { Square }\end{array}$ & $\mathrm{F}$ & Sig. \\
\hline $\begin{array}{ll}1 & \text { Regressio } \\
\mathrm{n}\end{array}$ &, 595 & 2 & ,298 & 5,215 &, $012^{\mathrm{b}}$ \\
\hline Residual & 1,655 & 29 & ,057 & & \\
\hline Total & 2,250 & 31 & & & \\
\hline
\end{tabular}

a. Dependent Variable: Quick Ratio

b. Predictors: (Constant), Perputaran Persediaan, Perputaran Kas

Sumber: data diolah 2018

Berdasarkan tabel diatas diperoleh nilai $\mathrm{F}_{\text {hitung }}=5,215>$ nilai $\mathrm{F}_{\text {tabel }}=3,33$ dengan nilai signifikan $0,012<0,05$. Maka dapat disimpulkan, bahwa perputaran kas dan perputaran persediaan secara simultan berpengaruh signifikan terhadap likuiditas (quick ratio).

\subsection{Uji Koefisien Determinasi $\left(\mathbf{R}^{2}\right)$}

Hasil output pengolahan data koefisien determinasi adalah sebagai berikut:

Tabel 5. Koefisien Determinasi

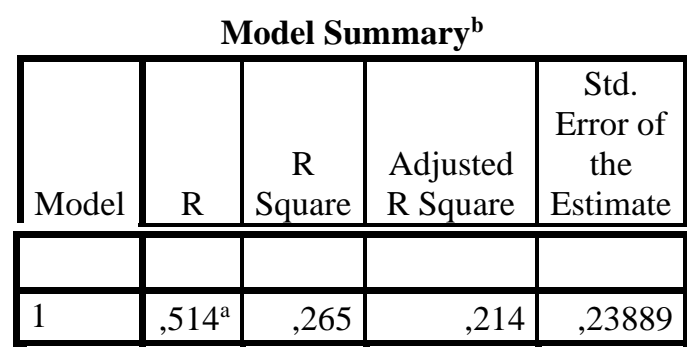

a. Predictors: (Constant), Perputaran

Persediaan, Perputaran Kas

b. Dependent Variable: Quick Ratio

Sumber: data diolah 2018

Berdasarkan tabel diatas hasil uji koefisien determinasi dapat dilihat nilai $\mathrm{R}$ squaer sebesar 0,265, sehingga perputaran kas dan perputaran persediaan secara 
bersamaan mempengaruhi likuiditas (quick ratio) sebesar $26,5 \%$ dan sisanya $73,5 \%$ dari nilai likuiditas (quick ratio) yang dipengaruhi oleh faktor lain yang tidak digunakan dalam penelitian ini.

\subsection{Pembahasan}

Pengaruh Perputaran Kas dan Perputaran Persediaan Terhadap Likuiditas (Quick Ratio).

Berdasarkan analisis yang dilakukan terdapat pengaruh dan signifikan perputaran kas dan perputaran persediaan secara simultan terhadap likuiditas (quick ratio). Pada tabel 4.6 diatas dimana variabel perputaran kas dan perputaran persediaan memiliki nilai $F_{\text {hitung }}$ sebesar 5,215, nilai $F_{\text {tabel }}$ sebesar 3,33 ini menunjukan bahwa $\mathrm{F}_{\text {hitung }}>$ $F_{\text {tabel }}$ artinya variabel $\mathrm{X}_{1}$ dan $\mathrm{X}_{2}$ secara simultan berpengaruh terhadap $\mathrm{Y}$ dengan nilai signifikan $0,012<0,05$ maka $\mathrm{Ha}$ diterima. Hal ini sejalan dengan penelitian Indra Wijaya (2018) yang menyatakan perputaran kas, perpuataran piutang dan perputaran persediaan berpengaruh dan signifikan secara simultan terhadap likuiditas (quick ratio).

\section{Pengaruh Perputaran Kas Terhadap Likuiditas (Quick Ratio).}

Berdasarkan analisis yang dilakukan terdapat pengaruh negatif dan signifikan perputaran kas secara parsial terhadap likuiditas (quick ratio). Pada tabel 4.7 variabel perputaran kas $\left(\mathrm{X}_{1}\right)$ memproleh nilai
$\mathrm{T}_{\text {hitung }}$ sebesar -3,229 nilai $\mathrm{T}_{\text {tabel }}$ sebesar 2,045 ini menunjukan bahwa $\mathrm{T}_{\text {hitung }}>\mathrm{T}_{\text {tabel }}$ artinya variabel $\mathrm{X}_{1}$ secara parsial berpengaruh negatif terhadap $\mathrm{Y}$ dengan nilai signifikan $0,003<0,05$ maka Ha diterima. Hal ini sejalan dengan penelitian Indra Wijaya (2018) yang menyatakan bahwa perputaran kas berpengaruh negatif dan signifikan secara parsial terhadap likuiditas (quick ratio).

\section{Pengaruh Perputaran Persediaan Terhadap Likuiditas (Quick Ratio).}

Berdasarkan analisis yang dilakukan terdapat pengaruh dan signifikan perputaran persediaan secara parsial terhadap likuiditas (quick ratio). Pada tabel 4.7 variabel perputaran persediaan $\left(\mathrm{X}_{2}\right)$ memproleh nilai $\mathrm{T}_{\text {hitung }}$ sebesar 2,828 nilai $\mathrm{T}_{\text {tabel }}$ sebesar 2,045 ini menunjukan bahwa $\mathrm{T}_{\text {hitung }}>\mathrm{T}_{\text {tabel }}$ artinya variabel $\mathrm{X}_{2}$ secara parsial berpengaruh terhadap Y dengan nilai signifikan 0,008 < 0,05 maka Ha diterima. Hal ini sejalan dengan penelitian Indra Wijaya (2018) yang menyatakan bahwa perputaran persediaan berpengaruh dan signifikan secara parsial terhadap likuiditas (quick ratio).

\section{KESIMPULAN DAN SARAN}

\subsection{Kesimpulan}

Berdasarkan hasil penelitian yang telah diteliti mengenai pengaruh perputaan kas dan perputaran persediaan terhadap likuiditas (quick ratio), maka dapat disimpulkan sebagai berikut: 
1. Hasil uji simultan menunjukan bahwa terdapat pengaruh dan signifikan secara simultan antara perputaran kas dan perputaran persediaan terhadap likuiditas (quick ratio) pada PT Indofood CBP Sukses Makmur Tbk.

2. Hasil uji parsial menunjukan bahwa terdapat pengaruh negatif dan signifikan secara parsial antara perputaran kas terhadap likuiditas (quick ratio) pada PT Indoofod CBP Sukses Makmur Tbk.

3. Hasil uji parsial menunjukan bahwa terdapat pengaruh dan signifikan secara parsial antara perputaran persediaan terhadap likuiditas (quick ratio) pada PT Indoofod CBP sukses Makmur Tbk.

\subsection{Saran}

Setelah dikemukakan beberapa kesimpulan berdasarkan penelitian pada PT Indofood CBP Sukses Makmur Tbk, maka penulis dapat memberikan saran senagai berikut:

1. Untuk perusahaan PT Indofood CBP Sukses Makmur Tbk, agar mampu meningkatkan pengelolaan kas dan persediaan untuk memaksimalkan aktiva lancar perusahaan yang akan digunakan untuk membayar hutang jangka pendek perusahaan.

2. Perputaran kas yang masih belum efisien agar dapat ditingkatkan dengan meningkatkan penjualan kredit agar perputaran kas dapat menghasilkan laba secara maksimal dalam perusahaan.
3. Pihak manajemen harus mengontrol modal kerja dengan cara menjaga kenaikan hutang lancarnya agar tidak terlalu besar serta memperkecil aktiva lancarnya supaya modal kerja tidak terlalu tinggi.

\section{DAFTAR PUSTAKA}

Fahmi, Irham. 2012. Analisis Laporan Keuangan. Bandung: Alfabeta.

Ghozali, Imam. 2016. Aplikasi Analisis Multivariate dengan Program SPSS. Edisi Kesembilan. Semarang: Badan Penerbit Universitas Diponegoro.

Harapah,Sofyan Syafitri. 2013. Analisis Kritis Atas Laporan Keuangan. Jakarta: PT Raja Grafindo Prsada.

Hendayani, Ratih. 2016. Mari Berkenalan dengan Manajemen Ligistik. Bandung: Alfabeta.

Hery. 2015. Analisis Laporan Keuangan. Jakarta: PT Bumi Aksara.

Jumingan. 2014. Analisa Laporan Keuangan. Jakarta: PT Bumi Aksara.

Kasmir. 2014. Analisis Laporan Keuangan. Jakarta: PT Raja Grafindo Persada.

Kartikahadi, Hans. Dkk. 2012. Akuntansi Keuangan Berdasarkan SAK Berbasis IFRS. Jakarta: Salemba Empat.

Munawir. 2014. Analisa Laporan Keuangan. Yogyakarta: Penerbit Liberty.

Mamduh M. Hanafi. 2014. Analisis Laporan Keuangan. Edisi 7. Yogyakarta: UPP STIM YKPN.

Permata, Lolyta. 2011. Pengaruh Perputaran Kas Terhadap Likuiditas Pada Perusahaan Perdagangan di Bursa Efek Indonesia. Jurnal Al- hikmah. Riau: Fakultas Agama Islam (FAI) Universitas Islam Riau. 
Rahayu, Mustika Devy. 2015. Pengaruh Perputaran Piutang dan Perputaran Kas Terhadap Tingkat Likuiditas Pada Perusahaan Manufaktur Sektor Farmasi Yang Terdaftar di Bursa Efek Indonesi Tahun 2009-2012. Bandung: Sekolah Tinggi Ilmu Ekonomi (STIE) Ekuitas Bandung.

Riyanto, Bambang. 2013. Dasar-dasar Pembelajaran Perusahaan. Yogyakarta: BPFE.

Rudiyanto. 2012. Konsep dan Teknik Penyusunan Laporan Keuangan. Jakarta: Erlangga.

Siregar, Soyfian. 2015. Statistika Parametrik Untuk Penelitian Kuantitatif. Jakarta : PT Bumi Aksara.

Stice, James D., Stice, Earl K., Skousen, Fred K. 2013. Akuntansi Keuangan. Jakarta: Salemba Empat.

Sugiyono. 2016. Metode Penelitian Kuantitatif, Kualitatif dan $R \& D$. Bandung: CV Altabeta.

Sujarweni, V Ratna. 2014. Metodelogi Penelitian. Yogyakarta : Pustaka Baru Press.

Wijaya, Indra. 2018. Pengaruh Perputaran Kas, Perputaran Piutang dan Perputaran Persediaan Terhadap Likuiditas Perusahaan Sub Sektor Logam dan Sejenisnya Yang Terdaftar di BEI 2011-2016. Program Studi Magister Manajemen Fakultas Ekonomi dan Bisnis. Krawang: Universitas Singaperbangsa Karawang.

www.idnfinancials.com

www.idx.co.id

www.indofoodcbp.com

www.katadata.co.id 